\title{
Susceptibility of Certain Maize Varieties to Tetranychus urticae Koch Infestation in Relation to Leaf Chemical Contents
}

\author{
Hala M.I. Mead; H.M.G. El-Kawas*; W.M.H. Desuky \\ Plant Protection Research Institute, Agriculture Research Center, Dokki, Giza, Egypt, hmg731@yahoo.com \\ (Received: January 5, 2010)
}

\begin{abstract}
Field studies were carried out to evaluate six single cross maize hybrids namely; Giza 129, Giza 10 \& Giza 125 (white maize varieties) and Giza 168, Giza $162 \&$ Giza 166 (yellow maize varieties) for their relative susceptibility to the twospotted spider mite, Tetranychus urticae Koch infestation, during 2008 and 2009 growing seasons at Sharkia Governorate, Egypt. Giza 125 and Giza 162 proved to be the most susceptible hybrids to spider mite infestation in white and yellow maize varieties, respectively, while Giza 129 and Giza 166 were the most tolerant in the two varieties, respectively. In both tested seasons, mite population reached its peak on maize during the fourth and the third weeks of July, respectively, for all tested hybrids. A significant positive correlation was found between mite infestation and both nitrogen and protein contents in maize leaves.
\end{abstract}

Key Words: Susceptibility, Zea mays, Tetranychus urticae, Population, Maize hybrids, Chemical contents.

\section{INTRODUCTION}

Maize (Zea mays L.) occupies an important position among cereal crops in Egypt. Although it was planted principally for animal feed, yet it is also important as stable food crop for birds and contributes in human feed as a maize oil and partially in bread.

Maize plants are infested with several pests, of which T. urticae is considered important (Abd-ElShaheed et al. 1975, Abo-Korah, 1983 and Zaher et al. 1980). Bacon et al., 1962 found a $47 \%$ reduction in maize yield resulting from damage by $T$. urticae. Mite infestation differs according to maize varieties (Sawiris, 1992). This difference may be attributed to plant leaf morphology or its chemical contents.

Many studies are focused on new tolerant plant varieties that received the lowest infestation of mites and consequently increased the crop yield (Ahmed, 1994 and El-Sanady et al., 2008). Additionally, the relation between chemical contents of leaves and mite infestation was discussed by several authors (Zaher et al., 1980, Trindade and Chiavegato, 1999; Hoffland et al., 2000 and Hole \& Salunkhe, 2005) to create unfavorable conditions for spider mite development, thus reduce their injuriousness on plants.

Therefore, the aim of the present work was to evaluate six single cross maize hybrids belonging to two maize varieties (white and yellow) for their relative susceptibility to $T$. urticae infestation during two successive growing maize seasons; 2008 and 2009. In addition, the population dynamic of the mite throughout the two seasons was studied. The relationship between mite infestation and maize leaves chemical contents was investigated.

\section{MATERIALS AND METHODS}

\section{1- Field trials:}

An area of about quarter feddan (1 feddan= $4200 \mathrm{~m}^{2}$ ) at Zagazig district, Sharkia Governorate, Egypt was divided into 24 plots, four of which as replicates were cultivated with one of the six maize hybrids. Maize seeds were sown in rows $7 \mathrm{~m}$. long and $80 \mathrm{~cm}$. in between at a distance of $25 \mathrm{~cm}$. between hills at nearly end of May, during 2008 and 2009 growing maize seasons, (Table 1).

Table (I): Tested maize hybrids (Zea mays L.)

\begin{tabular}{lc}
\hline Maize varieties & Hybrids \\
\hline \multirow{2}{*}{ White } & Giza 10 \\
\cline { 2 - 2 } & Giza 125 \\
\hline \multirow{2}{*}{ Yellow } & Giza 129 \\
\cline { 2 - 2 } & Giza 162 \\
\cline { 2 - 2 } & Giza 166 \\
\hline
\end{tabular}

All plots received normal agricultural processes without using pesticides. Throughout the two growing seasons, weekly samples, each of five 5 leaves / plot ( 20 leaves per each hybrid) from $22^{\text {nd }}$ June to $25^{\text {th }}$ August were examined for T. urticae moving stages. Two square inches around mid rib of leaf were examined. Each hybrid was represented by 20 leaves $\times 10$ sampling dates.

\section{2- Phytochemical analysis of maize leaf varieties:}

Leaf samples of the six maize hybrids cultivated in 2009 season, were picked up during the 
vegetation period, cleaned, washed with distilled water, and dried in an oven at $70^{\circ} \mathrm{C}$ for $48 \mathrm{hr}$., then grinded into fine powder. The total carbohydrate and total protein were estimated according to the methods of Miller (1959) and Chapman \& Pratt (1961), respectively. Nitrogen, phosphorus and potassium were also determined as the methods described by Black (1965); Murphy \& Riely (1962) and Dewis \& Freites (1970), respectively.

\section{Statistical analysis:}

Data were analyzed by one-way analysis of variance (ANOVA) to test the significant differences between mean values and correlation coefficient between the spider mite population and chemical contents of maize leaves using Costat software (Anonymous, 1990).

\section{RESULTS AND DISCUSSION}

\section{1- Susceptibility of maize varieties to $T$. urticae infestation}

Data given in Table (2) indicate that the tested maize varieties significantly differed in their susceptibility to $T$. urticae infestation according to the mean number of movable mite stages / 100 square inches existed throughout 2008 and 2009 seasons on samples collected from each hybrid.

Table (2): Susceptibility of maize varieties to $T$. urticae infestation during 2008 and 2009 seasons

\begin{tabular}{|c|c|c|c|}
\hline \multirow{2}{*}{ 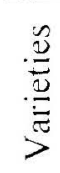 } & \multirow{2}{*}{ Hybrids } & \multicolumn{2}{|c|}{$\begin{array}{l}\text { Mean no. of moving stages } \\
\text { during season } / 100 \text { square inches }\end{array}$} \\
\hline & & 2008 & 2009 \\
\hline & Gizal25 & $3884.62 \pm 40.71^{\mathrm{a}}$ & $4981.60 \pm 183.5^{\mathrm{a}}$ \\
\hline & $\overline{\text { Giza } 10}$ & $2512.28 \pm 150.26^{b}$ & $2705.08 \pm 69.91^{b}$ \\
\hline & Giza 129 & $780.42 \pm 07.07^{\circ}$ & $717.60 \pm 42.84^{\mathrm{c}}$ \\
\hline & $\overline{L S D}_{0.15}$ & 287.85 & 269.20 \\
\hline \multirow{4}{*}{$\stackrel{\frac{3}{0}}{\frac{0}{2}}$} & Gizal 62 & $4800.12 \pm 84.22^{\mathrm{a}}$ & $5128.8 \pm 77.94^{\mathrm{a}}$ \\
\hline & Gizal 68 & $1660.42 \pm 37.28^{b}$ & $1936.28 \pm 126.07^{b}$ \\
\hline & Gizal 66 & $1244.48 \pm 70.26^{\circ}$ & $1436.00 \pm 46.49^{c}$ \\
\hline & $\operatorname{LSD}_{005}$ & 213.98 & 223.24 \\
\hline
\end{tabular}

In white maize hybrids, the single cross hybrid, Giza 125 was the most highly significant susceptible to infestation recording $3884.62 \pm 40.71$ and $4981.60 \pm 183.51$ moving mite stages during the two successive seasons 2008 and 2009, respectively, followed by the moderately infested hybrid Giza 10 receiving $2512.28 \pm 150.26$ and $2705.08 \pm 69.91$ movable mite individuals, respectively. Single cross hybrid, Giza 129 was the most tolerant one that gave the lowest significant difference in the number of mite infestations (780.42 = ${ }^{-}{ }^{-}$and $\left.{ }^{-} 1^{-} .60 \pm 42.84\right)$, respectively.

Whereas yellow maize hybrids ranged between $4800.12 \pm 84.22$ and $5128.80=7.9+$ movable mite individuals for the most susceptible hybrids, Giza 162 in the two maize growing seasons 2008 and 2009, respectively. to $1244.48 \pm 70.26$ and $1436.00 \pm 49.49$ movable mite individuals, respectively, for Giza 166 which considered the most tolerant one.

\section{2- Population dynamic of $T$. urticae on maize varieties during 2008 and 2009 growing seasons}

As shown in Figs. (1\&2), T. urticae occurred during the two seasons from $22^{\text {nd }}$ June to $25^{\text {th }}$ August. During the first season, the infestation of mite moving stages occurred in few numbers after 25 days of sowing date on all tested varieties. A definite trend in population dynamic was observed, the population increased slowly until about July $1^{\text {st. }}$, then it sharply increased until reached its peak during the fourth week of July. This result was observed by all tested maize hybrids with different degrees. Subsequently, the number of mites decreased gradually until the end of the season.

The same trend was obtained during the second season with the exception of that all the tested hybrids reached its peak during the third week of July.

Generally, it was appearent, that all the tested hybrids exhibited higher numbers of T. urticae in the second season than in the first one, Figs. $(1 \& 2)$.

Based on the seasonal mean of the population in the white maize hybrids, Giza 125 was the most susceptible one that infested with 188.00 and 250.47 individuals (mean number of moving mite stages/10 square inches) in 2008 and 2009 seasons, respectively. On the contrary, Giza 129 hybrid was the most tolerant one recording 35.00 and 36.40 individuals, during the two growing seasons, respectively (Figs. 1, A \& 2, A).

In case of yellow maize hybrids, Giza 166 showed highest tolerance than other hybrids followed by Gizal 68 and Giza 162 that infested by $(62.00 \& 69.00),(77.00 \& 8407)$ and $(242.00 \&$ $262.60)$ mite movable stages in both maize seasons. respectively, (Figs. 1, B \& 2, B).

Margoli and Kennedy (1984); Taha (1992). Magouz et al., (2006) and El-Sanady et al., (2008) 

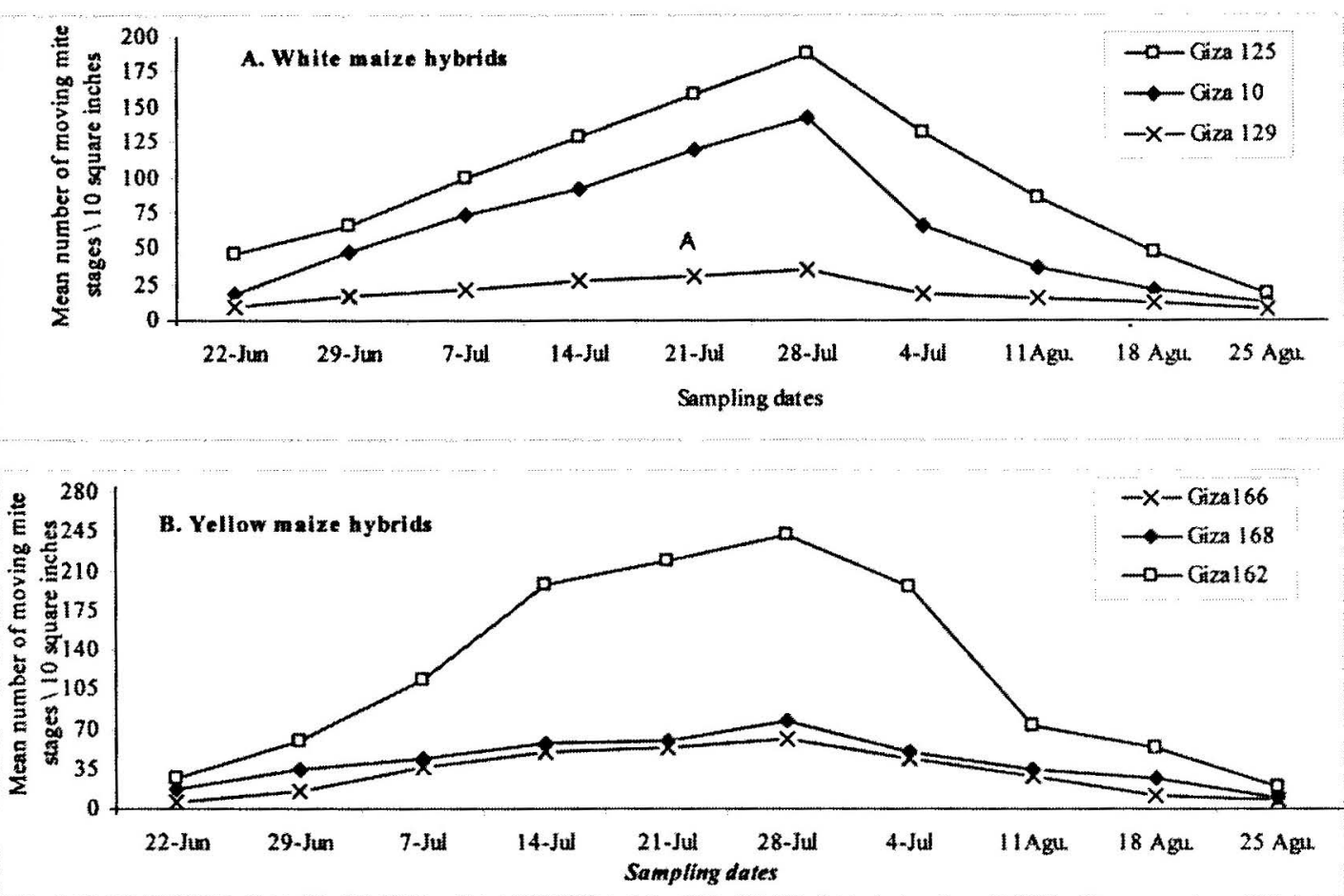

Fig. (1, A-B): Population dynamics of T. urficae infestation on white and yellow maize varieties at Sharkia

Governorate during the 2008 growing season.
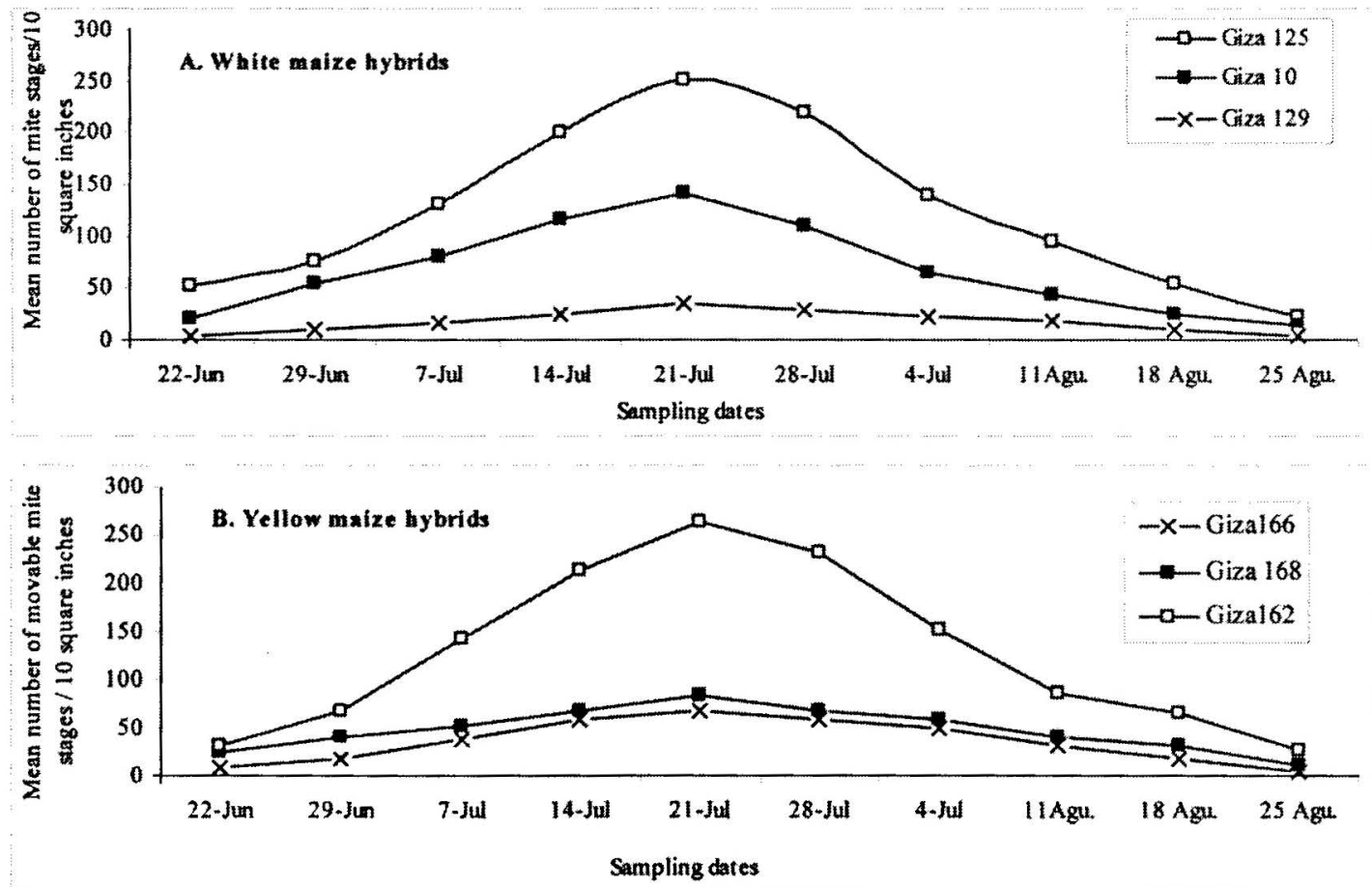

Fig. (2, A-B): Population dynamics of T. urticae infestation on white and yellow maize varieties at Sharkia Governorate during the 2009 growing season. 
recorded the same conclusion when studied the population fluctuation of $T$. urticae on maize and soybean varieties.

\section{3- Relationship between mite infestation and chemical contents of maize leaves}

Total carbohydrates, total protein, nitrogen, phosphorus and potassium were estimated in maize leaves during 2009 growing season.

As shown in Fig. (3, B\&C), data and statistical analysis cleared that the total protein and nitrogen contents in the white hybrids, ranged between $44.66 \pm 3.92$ and $3.63 \pm 0.31 \mathrm{mg} / \mathrm{gm}$ dry weight for the most significant susceptible hybrid, Giza 125 to $29.00 \pm 2.81$ and $2.63 \pm 0.63 \mathrm{mg} / \mathrm{gm}$ dry $w \mathrm{t}$. for the highly significant tolerant hybrid, Giza 129, respectively. As for yellow hybrids, the values for total protein and nitrogen content ranged between $37.66 \pm 2.33$ and $3.13 \pm 0.20 \mathrm{mg} / \mathrm{gm}$ dry wt. for the highly significant susceptible hybrid, Giza 162 to $31.00 \pm 5.03$ and $2.43 \pm 0.17 \mathrm{mg} / \mathrm{gm}$ dry wt. for the most tolerance hybrid, Giza 166, respectively.

The same trend was recorded in the case of phosphorus content among the yellow maize hybrid Giza 166 where it was the most susceptible giving $3.30 \pm 0.15 \mathrm{mg} / \mathrm{gm}$ dry wt., while Giza 166 appeared to be the lowest infested one giving $1.41 \pm 0.07 \mathrm{mg} /$ gm dry wt., Fig. (3, D).

On the other hand, the quantities of the total carbohydrates and potassium in maize leaves were slightly compared to the total protein and nitrogen. The higher amounts of both total carbohydrates and potassium were presented in Giza 168 and Giza 162 hybrids that gave $11.30 \pm 0.35 \mathrm{mg} / \mathrm{gm}$ dry wt., and $99.00 \pm 4.58 \mathrm{mEq} /$ gm dry wt., respectively.

While the lower amounts recorded were $9.36 \pm$ $0.18 \mathrm{mg} / \mathrm{gm}$ dry wt. and $70.66 \pm 3.71 \mathrm{mEq} / \mathrm{gm}$ dry wt. for Giza 166 and Giza 10 hybrids, respectively (Fig. 3, A-E).

Positive correlation. was obtained only between mite infestation and both nitrogen and total protein contents in maize leaves (Table, 3 ).

The most susceptible single cross hybrids, Gizal25 and 162 gave positive significant correlation with total protein and nitrogen comparing with other white and yellow maize hybrids, respectively. The statisticale analysis showed a negative insignificant correlation between number of moving mite stages and total carbohydrates in maize leaves
Table (3): Correlation coefficient between the population of $T$. urticae and phytochemical contents of maize leaves during 2009 growing season.

\begin{tabular}{cccccc}
\hline $\begin{array}{c}\text { Maize } \\
\text { hybrids }\end{array}$ & $\begin{array}{c}\text { Total } \\
\text { Carbohyd. }\end{array}$ & $\begin{array}{c}\text { Total } \\
\text { protein }\end{array}$ & $\mathrm{N}$ & $\mathrm{P}$ & $\mathrm{K}$ \\
\hline Giza 10 & -0.383 & 0.987 & 0.976 & -0.077 & -0.943 \\
\hline Giza 125 & -0.614 & $0.997^{*}$ & $0.994^{*}$ & -0.387 & -0.954 \\
\hline Giza 129 & -0.141 & 0.864 & 0.985 & -0.512 & -0.984 \\
\hline Giza 162 & -0.727 & $0.989^{*}$ & $0.975^{*}$ & 0.838 & 0.188 \\
\hline Giza 166 & -0.428 & 0.920 & 0.853 & 0.550 & 0.676 \\
\hline Giza 168 & -0.094 & 0.949 & 0.876 & 0.603 & 0.856 \\
\hline
\end{tabular}

Similar results were obtained by Sawires (1992) when testing spider mite infestation and chemical contents of maize leaves. Ahmed (1994) suggested that resistance may be attributed to low protein and amino acid contents of leaves, which provided less nutritive diet for $T$. urticae. The resistance cultivars of rose, which recorded lowest spider mite population, had lower amounts of nitrogen and higher amounts of carbohydrates than the more susceptible cultivars (Hole \& Salunkhe, 2005).

Tulisalo (1972) reported that, fecundity of T. urticae was independent of variations in type and levels of carbohydrates because of different pathways for carbohydrate metabolism exist. In addition, Zaher et al., (1980) found insignificant positive correlation between infestation of soybean with $T$. urticae and leaf nitrogen contents. In contrary, Magouz et al., (2006) and El-Sanady et al. (2008) reported a negative correlation between the population density of moving mite stages and nitrogen contents in soybean leaves.

The obvious correlation between spider mite infestation and both nitrogen and total protein contents in leaves may be explained by Hoffland et al., (2000) who found that, the protein concentration in tomato leaves is positively correlated with nitrogen availability. In comparing plant species as a host for mites, it was found that nitrogen levels in leaf tissues are positively correlated with rates of mite development and fecundity Hanna et al., (1982). Maia \& Busoli (1992) observed a reduction in the duration of pre-oviposition period and increase in oviposition period as the nitrogen contents increased. Furthermore, Trindade and Chiavegato (1999) observed that nitrogen and phosphorus deficiency or potassium excess caused reduction in the reproduction rate of $T$. urticae. In conclusion, white and yellow maize varieties, Giza 125 and Gizal62, respectively, were the most susceptible single cross hybrids to $T$. urticae 

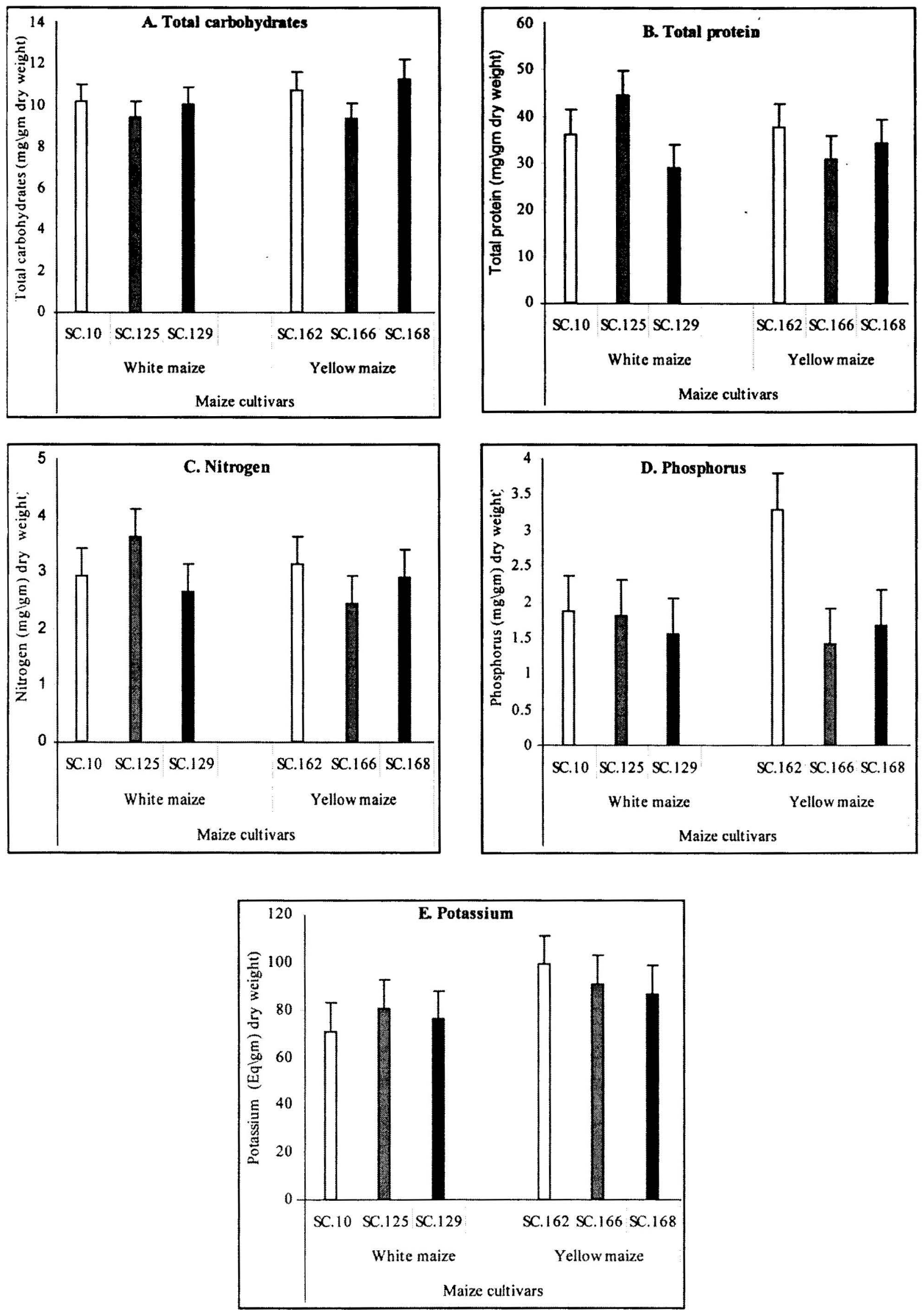

Fig. (3, A-E): Phytochemical analysis of dried leaves of white and yellow maize varieties during 2009 season. 
infestation. Also, a positive significant correlation occurred between spider mite infestation and both nitrogen and total protein contents in maize leaves.

\section{REFERENCES}

Abd-El-Shaheed, G.A.; Hammad, S.M. and ElSawaf, S.K., 1975. Survey and population density studies on mites found on cotton and corn in Abis, Abo Hommos localities, El-Beheira province (Egypt). Bull. Soc. ent. Egypt., 57: 101 108.

Abo-Korah, S.M., 1983. Mites associated with maize and their predators in Monofia Governorate, Egypt. Bull. Soc. ent. Egypt., 62: 275-278.

Ahmed, M.A., 1994. Differences in susceptibility of six cucumber cultivars infestation by Aphis gossypii Golv., Tetranychus urticae and Bemisia tabaci as correlated to protein and amino acid contents of leaves. Ann. Agric. Sci. Moshtor, 32: 2189-2194.

Anonymous 1990. Costat Software, microcomputer program analysis version 4.20. CoHort Software, Berkeley, CA.

Bacon, O.G.; Lyons T. and Baskett, R.S., 1962. Effects of spider mite infestations on dent corn in California. J. Econ. Entomol. 55: 823-825.

Black, C.A., 1965. Methods of soil analysis. Amer. Soc. Agro., Inc. bub., Madison, Wisconsin MSA. Chapman, H.D. and Pratt, P.F., 1961. Methods of analysis for soils, plants and water. Univ. Cal.

Div. Agric. Science,USA, 150-152.

Dewis, J. and Freites, E., 1970. Physiological methods of soil and water analysis. Food Agric. organization of the united nations, Soils Bull., No. 10.

El-Sanady, M.A.; Soliman, S.M. and Younis, A.A., 2008. Field and laboratory studies to evaluate five soybean varieties for their relative susceptibility to the two spotted spider mite, Tetranychus urticae Koch infestation (Acarina: Tetranychidae: Actenidida). Egypt. J. Agric. Res., 86(1): 77-88.

Hanna, M.A.; Zaher, M.A. and Ibrahim, S.M., 1982. Some probable causes of host preference in six species of phytophagous mites. Zeitschrift fur Angewandte Entomologie, 93: 329-333.

Hoffland, E.; Dicke, M.; Tintelen, W.V.; Dijkman, H. and Beusichem, M.L.V., 2000. Nitrogen availability and defense of tomato against two spotted- spider mite., J. Chemical Ecology, 26:
2697-2711.

Hole, U.B. and Salunkhe G.N., 2005. Studies on the relative resistance of rose cultivars to two spotted spider mite (Tetranychus urticae Koch). J. Maharashtra Agric. Univ., 30: 316-317.

Magouz, R.I.E.; Saadoon, S.E. and Kassem, S.A.A., 2006. Population density of Tetranychus cucurbitacearum (Sayed) and Bemisia tabaci (Genn.) on certain soy bean varieties in relation to some water factors and leaf chemical contents. J. Agric. Res. Tanta Univ., 32(1): 90-102.

Maia. I.G. and Busoli, A.C., 1992. Effect of dosages and sources of nitrogen on the fecundity of Tetranychus urticae (Koch, 1836) on cotton CV. IAC 20 (Gossypium hirsutum L.). Anais da Sociedade Entomologica do Brasil, 21 347-356.

Margoli, D.C. and Kennedy G.G., 1984. Population response of the two-spotted spider mite, Tetarnychus urticae to host phenology in corn and peanut. Ent. Exp. Appl., 36(2): 193-196.

Miller, G.L., 1959. Use of dinitrosalicylic acid reagent for determination of reducing sugars. Anal. Chem., 31: 426-428.

Murphy, J. and Riely, J.P., 1962. A modified single solution for the determination of phosphate in natural water. Chem. Acta., 27: 31-36.

Sawires, Z.R., 1992. Susceptibility of maize varieties to mite infestation and toxicity of natural oils to mites. Egypt. J. Agric. Res., 70(1): 141-149.

Taha, H.A., 1992. Population dynamics of the twospotted spider mite, Tetranychus arabicus Attiah on some maize varieties. Egypt. J. Agric. Res., 70(1): 225-229.

Trindade, M.L.B. and Chiavegato, L.G., 1999. Effect of different levels of nitrogen, phosphorus and potassium on biological activity of Tetranychus (T.) urticae (Koch, 1836) (Acari: Tetranychidae) maintained on cotton plants cultivated in nutritive solution. UNESPCoordenadoria Geral de Bibliotecas, Marilia, Brazil, Cientifica (Jaboticabal), 27: 47-56.

Tulisalo, U., 1972: The effect of variations in the carbohydrate level of the host plant on the fecundity of the two-spotted spider mite, Tetranychus urticae Koch. Ann. Entomologici Fennici, 38: 179-182.

Zaher, M.A.; Hanna, M.A.; Mohamed, I.I. and Sawires, Z.R., 1980. Relative susceptibility of ten soybean varieties to mite infestation and probable causes of resistance. Proc. $1^{\text {th }}$ Conf. Plant Prot. Res. Ins., 3: 41-51. 